\title{
OAK RIDGE NATIONAL LABORATORY
}

operated by

UNION CARBIDE CORPORATION

for the

U.S. ATOMIC ENERGY COMMISSION

ORNL-TM- 1494

AN ANALOG COMPUTER STUDY OF THE CONTROL CHARACTERISTICS

OF THE MEDIUM POWER REACTOR EXPERIMENT SYSTEM

INCLUDING THE TURBINE-GENERATOR

(Title Unclassified)
O. W. Burke
S. J. Ditto
C. S. Walker 


\section{DISCLAIMER}

This report was prepared as an account of work sponsored by an agency of the United States Government. Neither the United States Government nor any agency Thereof, nor any of their employees, makes any warranty, express or implied, or assumes any legal liability or responsibility for the accuracy, completeness, or usefulness of any information, apparatus, product, or process disclosed, or represents that its use would not infringe privately owned rights. Reference herein to any specific commercial product, process, or service by trade name, trademark, manufacturer, or otherwise does not necessarily constitute or imply its endorsement, recommendation, or favoring by the United States Government or any agency thereof. The views and opinions of authors expressed herein do not necessarily state or reflect those of the United States Government or any agency thereof. 


\section{DISCLAIMER}

Portions of this document may be illegible in electronic image products. Images are produced from the best available original document. 
This report was prepared as an account of Government sponsored work. Neither the United States, nor the Commission, nor any person acting on behalf of the Commission:

A. Makes any warranty or representation, expressed or implied, with respect to the accuracy, completeness, or usefulness of the information contained in this report, or that the use of any information, apparatus, method, or process disclosed in this report may not infringe privately owned rights; or

B. Assumes any liabilities with respect to the use of, or for damages resulting from the use of any information, apparatus, method, or process disclosed in this report.

As used in the above, "person acting on behalf of the Commission" includes any employee or contractor of the Commission, or employee of such contractor, to the extent that such employee or contractor of the Commission, or employee of such contractor prepares, disseminates, or provides access to, any information pursuant to his employment or contract with the Commission, or his employment with such contractor. 
Contract No. W-7405-eng-26

INSTRUMENTATION AND CONTROLS DIVISION

AN ANALOG COMPUTER STUDY OF THE CONTROL CHARACTERISTICS

OF THE MEDIUM POWER REACTOR EXPERIMENT SYSTEM

INCLUDING THE TURBINE-GENERATOR

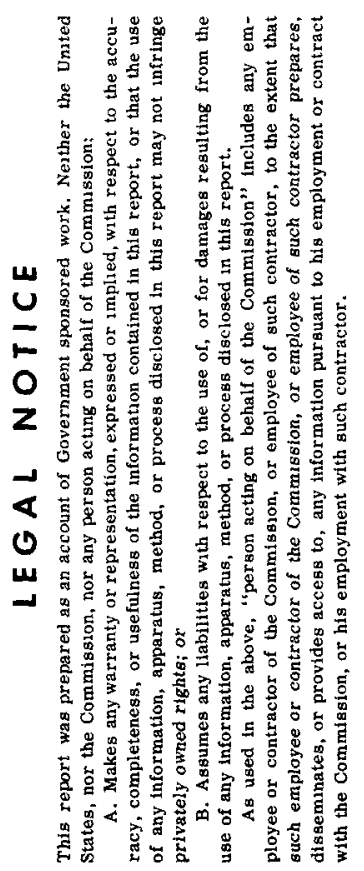

O. W. Burke, S. J. Ditto, and C. S. Walker

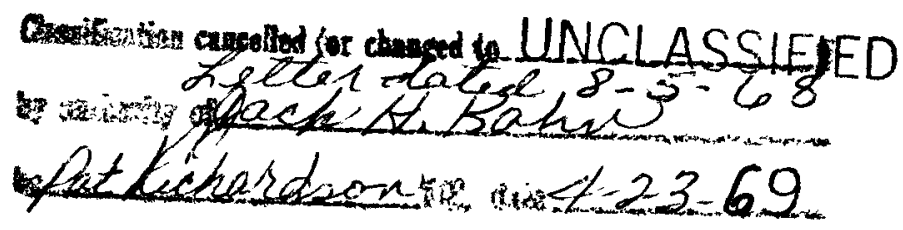

May 6, 1966

OAK RIDGE NATIONAL LABORATORY

Oak Ridge, Tennessee

operated by

UNION CARBIDE CORPORATION

for the

U.S. ATOMIC ENERGY COMMISSION
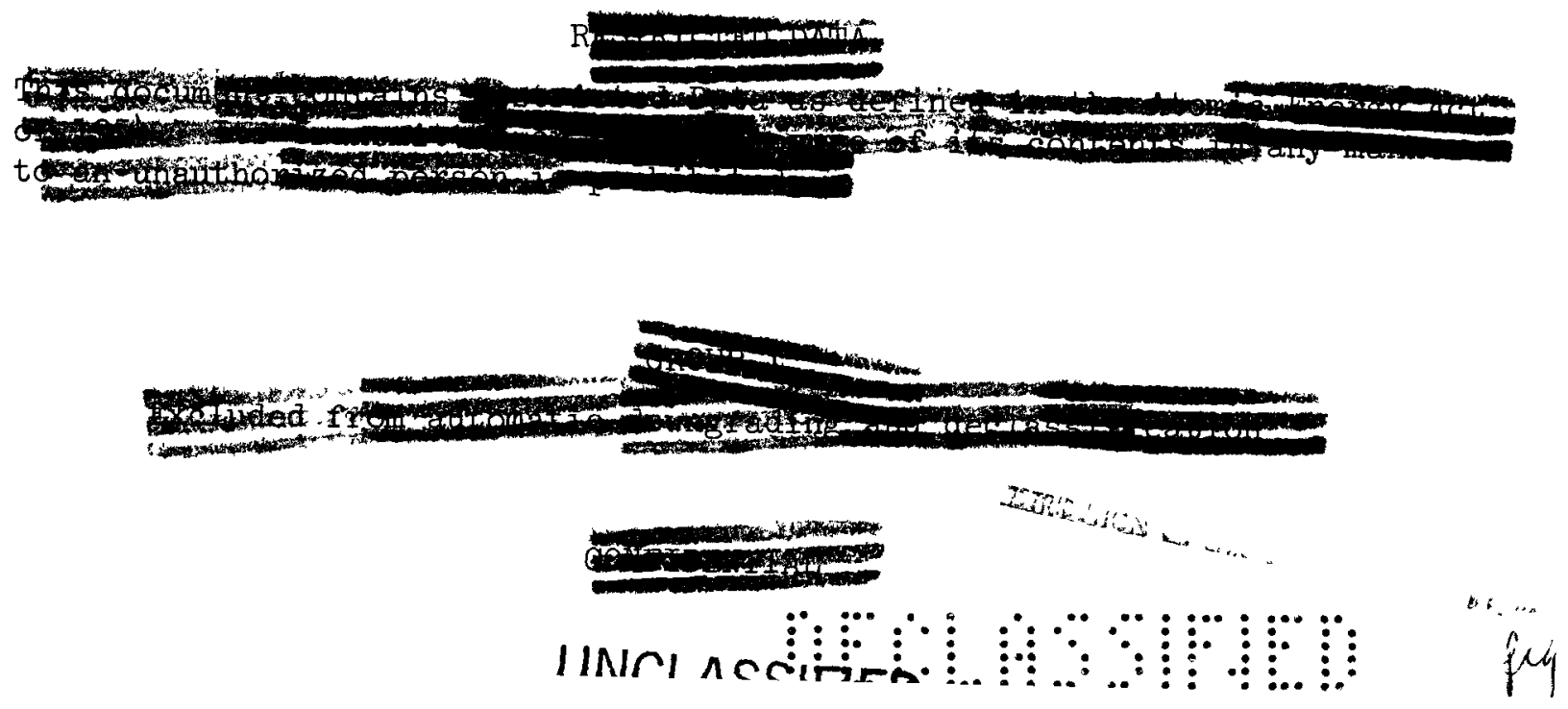
|

page blank 


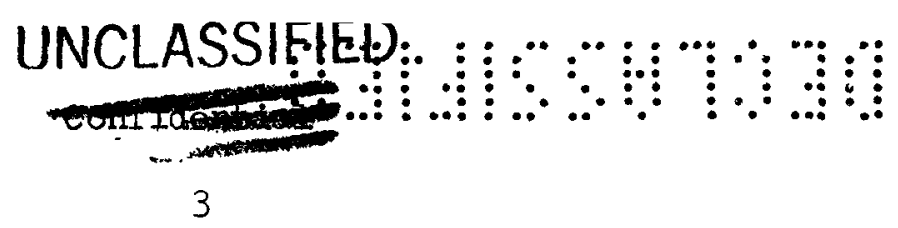

\begin{abstract}
The stability and control characteristics of the Medium Power Reactor Experiment (MPRE), including the turbine-generator unit and the reactor system, were investigated by means of an analog computer. The generator terminal voltage and frequency were controlled for two types of electrical loads. One load was entirely resistive and the other was similar to that imposed by induction motors driving pumps.

Two control schemes were used. In Control Scheme No. 1, the generator terminal voltage-error signal was the input to a controller which regulated the reactor control-plug position, and the generator frequency-error signal was the input to a controller which regulated the generator field current. The controller input signals were interchanged for scheme No. 2 .

The time lags for the system were found to be relatively short, the time constant for the boiler being about $12.5 \mathrm{sec}$. With a simple resistive load the system was found to be stable and controllable when using either control scheme; however, the response characteristics were much better for Scheme No. 1. With the simulated induction motor load, Scheme No. 2 gave acceptable results; however, the results for this load were not as good as those for the resistive load. Stable plant operation was not achieved when using Control Scheme No. I with the motor load.
\end{abstract}




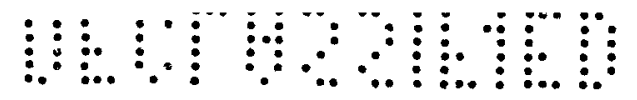

page blank 
Abstract

Introduction . . . . . . . . . . . . . . . 7

System Description . . . . . . . . . . . . . . 7

Analog Computer Simulation .............. 10

Controlled System Restrictions and Performance Requirements . . 10

Computer Run Descriptions and Results. . . . . . . . . 11

Conclusions. . . . . . . . . . . . . . . 19 
आआयแ।

page blank 


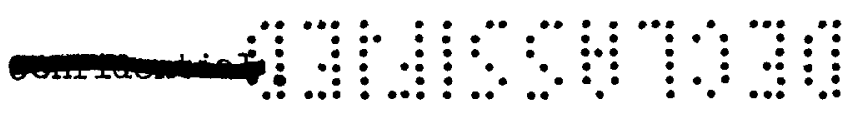

\section{INTRODUCTION}

One of the objectives of the MPRE design is to provide a reactor system that can be operated with a minimum of control equipment. The fluid system of the MPRE has the characteristic that the vapor flow rate to the turbine is independent of the turbine speed and depends only on the reactor power output. There is no throttle valve or parasitic electric load. The control system is required to maintain the generator output voltage and frequency within reasonable limits during and following load changes by controlling only the reactor power and the generator excitation. The range of such required control extends from approximately 20 to $100 \%$ of rated power.

The principal questions associated with plant control are concerned with the system time lags. The longest of these lags is the time required to sense an error in the controlled variable, move the reactor control plugs, and change the turbine input power sufficiently to reduce the error to an acceptable value. This lag could lead to control system complexities, poor dynamic response characteristics, coupled oscillations, and possible system instability. The time required to achieve a change in the generator field excitation should be relatively short and of little concern.

\section{SYSTEM DESCRIPIION}

The plant model used in this study was composed of portions of three separate designs. The 1-Mw MPRE was used as the Reactor, ${ }^{1,2}$ the piping configuration was that of a proposed MPRE launch package, ${ }^{3}$ and the turbine and generator were taken from SNAP-50 data. These subsystems were suitably scaled and integrated into a complete power plant.

The vapor mass flow rate through the turbine was computed as directly proportional to the inlet pressure and inversely proportional to the square root of the inlet temperature. ${ }^{1}$ For the narrow range of

${ }^{1}$ A. M. Perry, "Status of MPRE Core Design," paper presented at the AIAA First Rankine Cycle Space Power System Specialist Conference, Cleveland, Ohio, October 26-28, 1965 (to be published).

${ }^{2} \mathrm{M}$. E. La Verne, Control Concepts and Digital Computer Analysis of the MPRE Fluid System, ORNL-TM-1368 (Feb. 1966).

${ }^{3}$ A. P. Fraas, The MPRE -A Boil Potassium Reactor System, AIAA Paper 64-763, Third Biennial Aerospace Power systems Conference, Sept. 1-4, 1964 . 
operation used in this study, the turbine efficiency was assumed to be constant. The simulated generator was a scaled-down version of the SNAP-50 machine developed by the Westinghouse Electric Corporation personnel, and the model of the generator was based on their detailed analog computer study of the generator's electrical characteristics.4 The generator efficiency was assumed to be constant.

A functional block diagram of the power plant used for the study is shown in Fig. 1. Earlier analog work on the MPRE fluid system ${ }^{5}$ showed that a simulation of the boiler feed portion of the system requires much of the capacity of the available computer equipment, and yet this portion of the system has little effect on the time response of the boller. Since the control study was concerned primarily with the effects on controllability of time lags between the reactor and the turbine, it was decided that leaving out the condenser and boiler feed system would greatly simplify this investigation without seriously affecting the results. The coolant was assumed to enter the boiler as saturated liquid. The saturated liquid in the fluid stream leaving the boiler was recirculated, and the saturated vapor passed through the turbine and was dumped.

The nature of the electrical load to be imposed on the generator has not been defined. Two types of loads were simulated; one was a resistive load and the other was a simplified representation of induction motors driving fluid pumps. Although the power factor and current of an induction motor driving a pump are dependent on the impressed voltage and frequency, the effects of load changes on the generator terminal voltage were assumed to be identical with those of a resistive load. In the case of the resistive load, the generator electrical torque was computed as being proportional to electric load divided by frequency. In the case of the motor load, the generator electrical torque was computed as being directly proportional to the frequency multiplied by the number of connected motors. The simplification was made necessary by lack of information as to the nature of the load to be expected. When specific information becomes available, more precise models can be developed for the study of the control system and equipment of an actual power plant.

Simple, idealized, general purpose controllers were simulated. Each had an adjustable proportional band, an adjustable rate or derivative action, and an adjustable reset action. The reactor control-plug controller was operated in an "on-off" mode, with the dead band being

${ }^{4} \mathrm{C}$. I. Doughman, Snap-50/Spur Generator-Regulator Analog and Generator Saturation Curves, WAED 65.1E, Westinghouse Electric Corp., Lima, Ohio (Jan. 1965).

${ }^{5}$ A. R. Barbin and M. M. Yarosh, An Analog Study of a Single-Loop Rankine Cycle System, ORNL-TM-1369 (Jan. 1966). 
ORNL DWG 66-3712

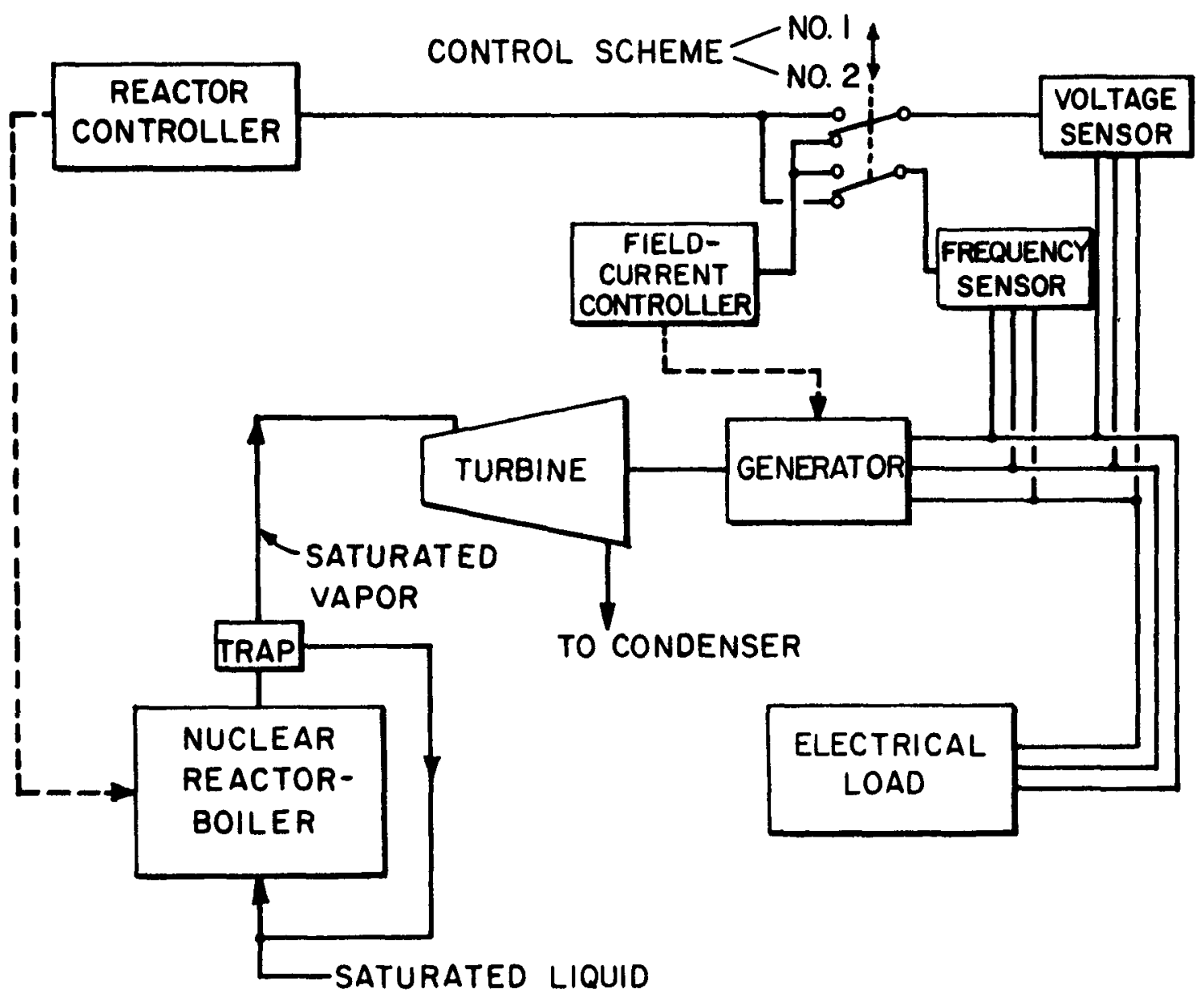

Fig. 1. Block Diagram of the Simulated System. 


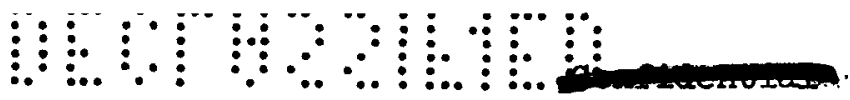

adjusted by variation of the proportional band setting. Various rod speeds were used. The field current controller had a first-order time lag of $0.632 \mathrm{sec}$ between detection of an error in the controlled variable and the resulting change in the field current. ${ }^{4}$

The particular controllers used in this study are not necessarily the most desirable ones for this application. Little effort was expended in attempting to optimize the gains associated with the proportional band, rate, and reset since further optimization would not have significantly altered the results of this study nor would they be useful for future analysis of a different system.

\section{ANALOG COMPUTER SIMULATION}

An analog computer model of the system shown schematically in Fig. I was developed. Confidence in the model was established by the close agreement between predicted and measured responses to perturbations introduced into the system. The time responses of the system to various stepwise perturbations in the absence of any control action were also obtained.

Two basic control schemes were used. In Scheme No. I a generator terminal voltage error signal was used to effect a change in reactor power through control plug motion and a generator frequency errorsignal was used to effect a change in the generator field current. In Scheme No. 2 the controller error signals were interchanged: a voltage error effected a field current change, and a frequency error effected a reactor power change.

\section{CONTROLUED SYSTEM RESTRICTIONS AND PERFORMANCE REQUIREMENTS}

The following restrictions and performance requirements were set up as tentative criteria for the system under study:

1. No throttle valve and no parasitic loads will be included in the design.

2. Step changes in electric load will be absorbed by allowing changes in generator terminal voltage and/or frequency.

3. The generator design will permit a 125\% overspeed condition.

4. Scheduled step changes in electrical load will not exceed $10 \%$ of the system capacity, and scheduled ramp changes will not exceed $0.5 \% / \mathrm{sec}$.

5. No single electrical load will absorb more than $20 \%$ of the generator rated output.

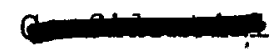




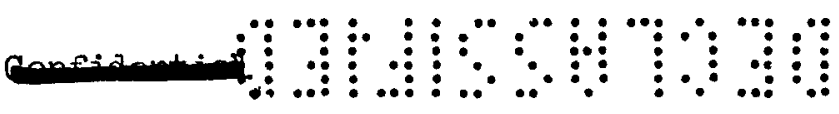

6. The time to achieve a 90,0 recovery of voltage and frequency following a step change in load of $20 \%$ will not exceed 1 min.

7. Under steady state conditions, the voltage and frequency will be held within at least $\pm 5 \%$, and preferably within $\pm 2 \%$, of their design values. If it does not involve much added complication, the frequency should be held within $\pm 0.5 \%$.

8. At reactor powers above 10 to $20 \%$, the reactor will be slaved to the generator output.

\section{COMPUTER RUN DESCRIPIIONS AND RESULTS}

Several analog computer runs were made and pertinent system variables were recorded as functions of time on an eight=channel recorder. A description of these runs and a discussion of results follow.

The first three computer runs were performed to study the plant response to step changes in reactor power, generator field current, and load resistance, respectively. No control actions followed the introduction of the step changes. The results of these runs are shown in Figs. 2, 3, and 4. In each case, the plant was operating in a steady state at design point prior to initiation of the transient. The load consisted of ten equal resistances connected in parallel.

The curves in Fig. 2 show the results of a step change in reactor power from 1 to $1.2 \mathrm{Mw}$. The generator field current and load resistance were held constant. As expected, the reactor power increase caused increases in fuel temperature, cladding temperature, potassium vapor temperature, boiler pressure, turbine speed, and generator voltage. The increase in turbine speed raised the voltage to bring the plant to a new steady state condition, wherein the electric power to the resistors was $120 \%$ or its original value. The potassium vapor temperature and boiler pressure approached their final values with a time constant (time to achieve $63 \%$ of the change) of about $12.5 \mathrm{sec}$. This time represented the thermal lag in the boiler. The time constant associated with the response of the turbine to the reactor power change was approximately $23 \mathrm{sec}$.

The effects of a step decrease of 10\% in generator field current are shown in Fig. 3. The reactor power and load resistance were held constant. The decrease in field current caused an immediate reduction in voltage, which reduced the electrical torque. The imbalance between turbine torque and electrical torque at the initial speed caused the turbine-generator to accelerate. A new equilibrium condition was reached when the speed increase caused the terminal voltage to return to its design point. At this condition, the electric power had returned to its original value, since the load resistance was constant. 
$\therefore: . .$.

$\vdots \ldots:$ :

$\because \cdots$

$\ldots$

$\because \because:$

$\because \because$

$\because \because \cdots$

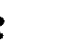

$\because \because$

$\vdots . .$.

$\because \cdots:$

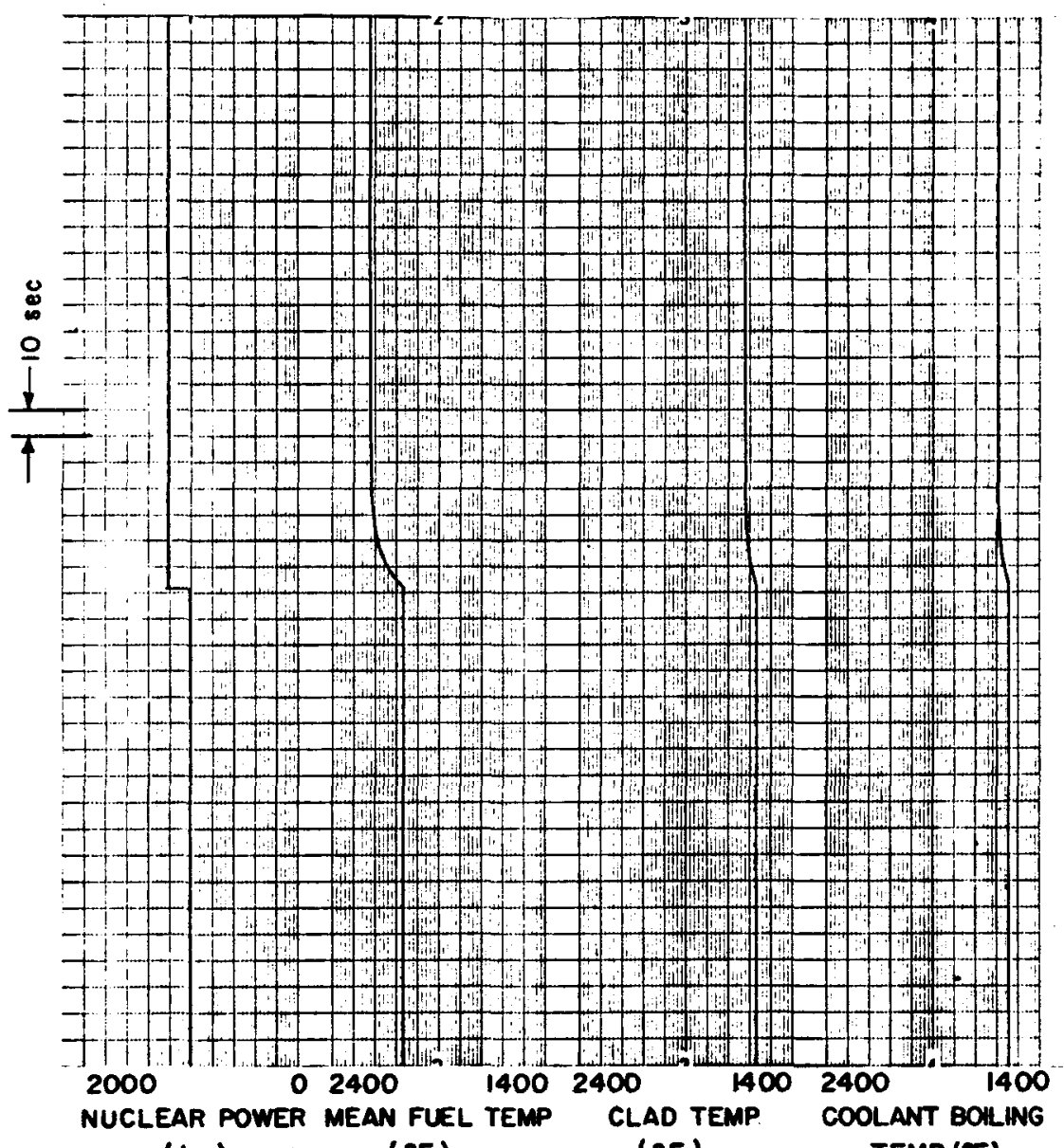

$(\mathrm{kw})$
( $P$ F)

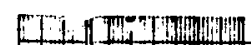

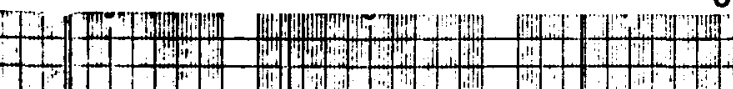

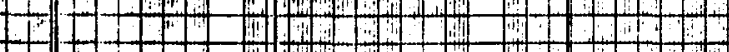
$-1+2$ $+2++4$ in $7+1+1$ $7 .+1 .+2$ $+1+1+$ iil $4+4 \longrightarrow+4$

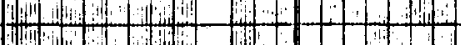

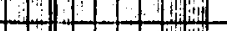

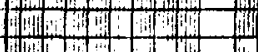

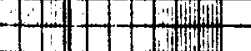

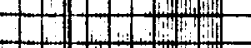

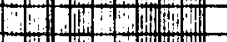

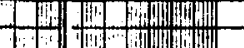

$+7+\ldots$

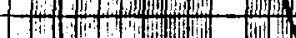

$+7+4+4$

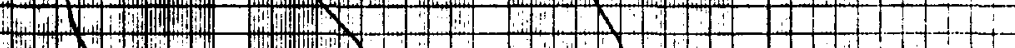

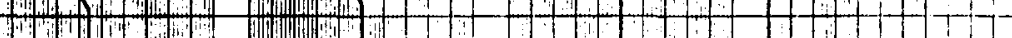

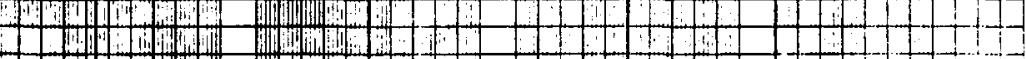
$40-1201-120$ -

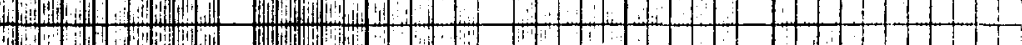

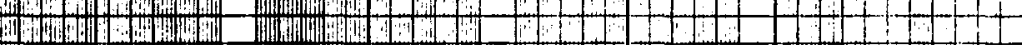

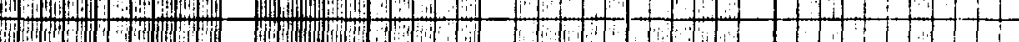
D

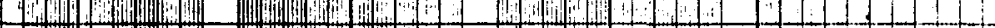

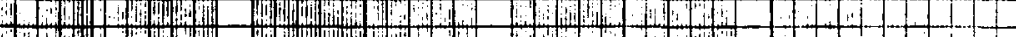

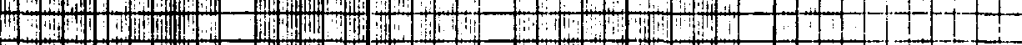

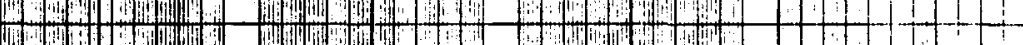

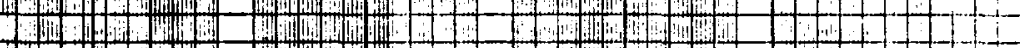

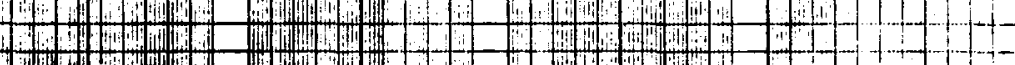

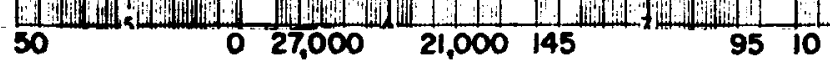
BOILER PRESS. TURBINE SPEED TERMINAL VOLTAGE (poio) $(\mathrm{rmm})$ (v)

NUMBER OF CONNECTED RESISTORS

Fig. 2. System Response to a $20 \%$ step Increase in Reactor Power with No Control. 
ORNL OWG 66-3639

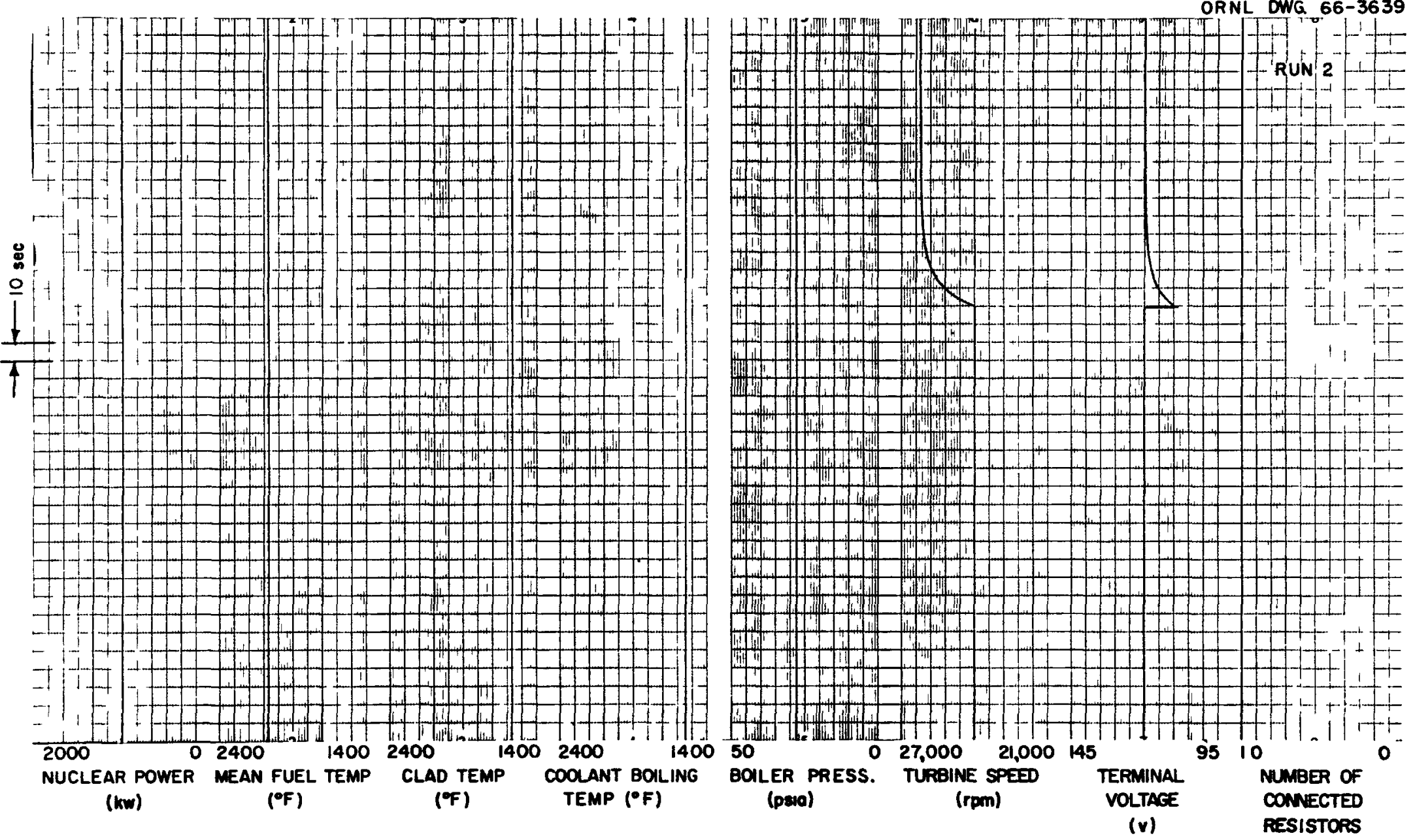

Fig. 3. System Response to a $10 \%$ step Decrease in Generator Field Current with No Control. 
$\therefore \ldots . .$.

$\vdots . . .:$

$\because \cdots$

$\ldots . . .:$

$\because \because$

$\because \because:$

$\because \because$

$\vdots \ldots .$.

$\because \because$

$\therefore$

$\therefore \ldots$
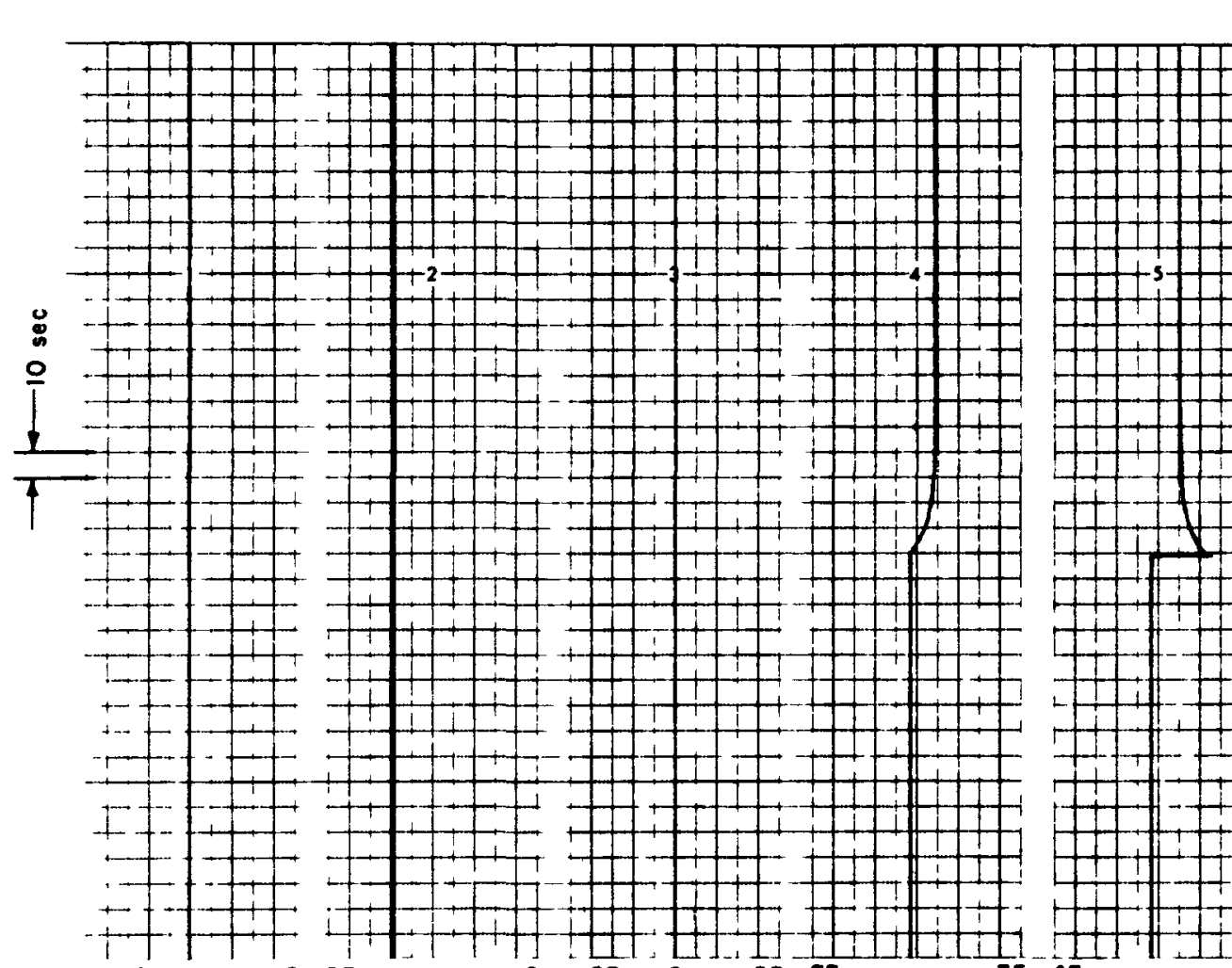

$0+.250-25 \quad-25$

$35 \quad 45$

2000 O 25

NUCLEAR POWE

(kw) \begin{tabular}{ll}
0 & 25 \\
\hline
\end{tabular} (omp)
(\%)
(Ib-ft)
ORNL DNG 66-3640

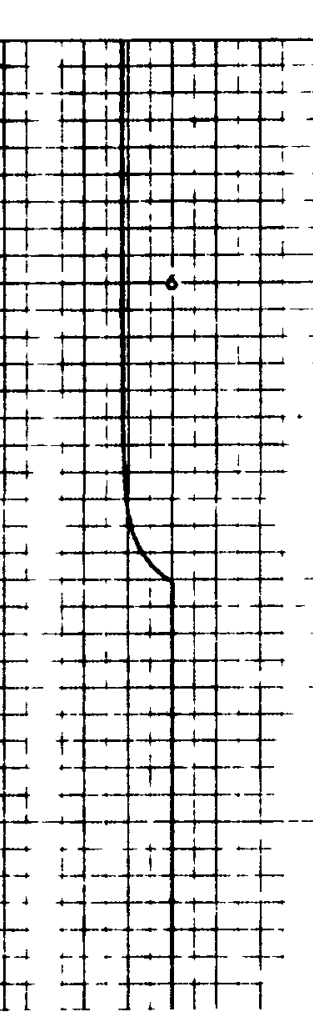

3527,000

$(16-t+)$
$21,000 \quad 145$

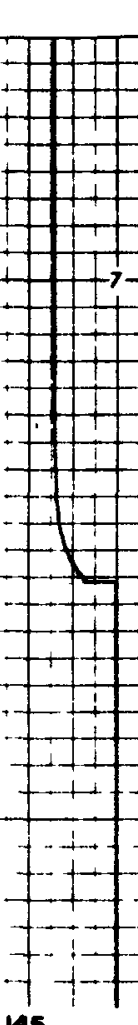

(rpm)

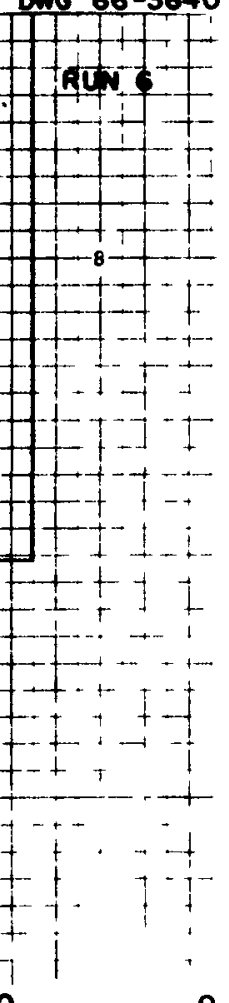

MUMBER OF

CONNECTED

RESISTORS

Fig. 4. System Response to a Sudden Loss of Two of the Ten Equal Load Resistors with No Control. 


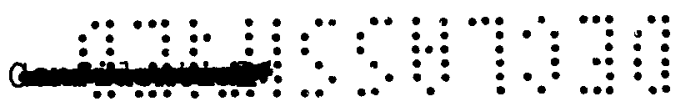

15

The results of disconnecting two of the ten equal load resistors are shown in Fig. 4. The immediate decrease in generator current (not recorded) allowed a corresponding step rise in terminal voltage, since the field current was constant. Despite the rise in terminal voltage, the net electrical torque was reduced. The unbalanced condition between the driving torque and electrical torque caused acceleration of the turbine-generator, which further increased the terminal voltage. A new equilibrium condition was established when the electrical power supplied to the load was returned to its original value. The eight load resistors remaining connected were absorbing the power originally absorbed by ten resistors.

The next two computer runs were performed to determine the performance of the plant after a step change in load resistance using both control schemes. The initial conditions for both of these runs were the same as for the previously described studies.

The curves of Fig. 5 show the results of disconnecting two of the ten equal load resistors when control scheme No. I was being used. As in the run illustrated in Fig. 4, the first effect is an increase in terminal voltage, followed by an increase in turbine speed. The increased voltage caused the reactor control-plug controller to decrease reactivity, which began reducing reactor power. The increase in turbine speed caused the field current controller to increase the field current. The interaction between field current, reactor power, frequency, and voltage resulted in some slight oscillations, but in about $100 \mathrm{sec}$ both the generator voltage and frequency were back to their original values. The reactor power had been reduced to $80 \%$, and the generator field current had been reduced slightly to a new steady state value.

The curves of Fig. 6 indicate the behavior of the system with control Scheme No. 2. Immediately after two of the ten loed resistors were disconnected, the voltage and turbine speed (frequency) began to increase as before. The frequency error caused insertion of control rods, and the voltage error caused a reduction in generator field current. The overshoots in both of the controlled variables were greater than those obtained using Scheme No. 1 ; however, the time to recover was about the same. Both power and frequency slowly oscillated after the voltage was brought back to its design value. The magnitudes of the oscillations were small and perhaps are acceptable.

The last run was made to determine control characteristics of the plant when the load is of the nature of induction motors driving fluid pumps. Scheme No. I could not be made to give stable system operation. The results of using Scheme No. 2 are shown in Fig. 7. The behavior after $20 \%$ of the motor loads were disconnected was very similar to the behavior when resistive loads were used and with the same control scheme. 
:...:

¿...:.

$\because .$.

....:.:

......

$: \because \because$

$\because \because$

•:

$\vdots . .$.

$\therefore \ldots$

!...:.

:.....:

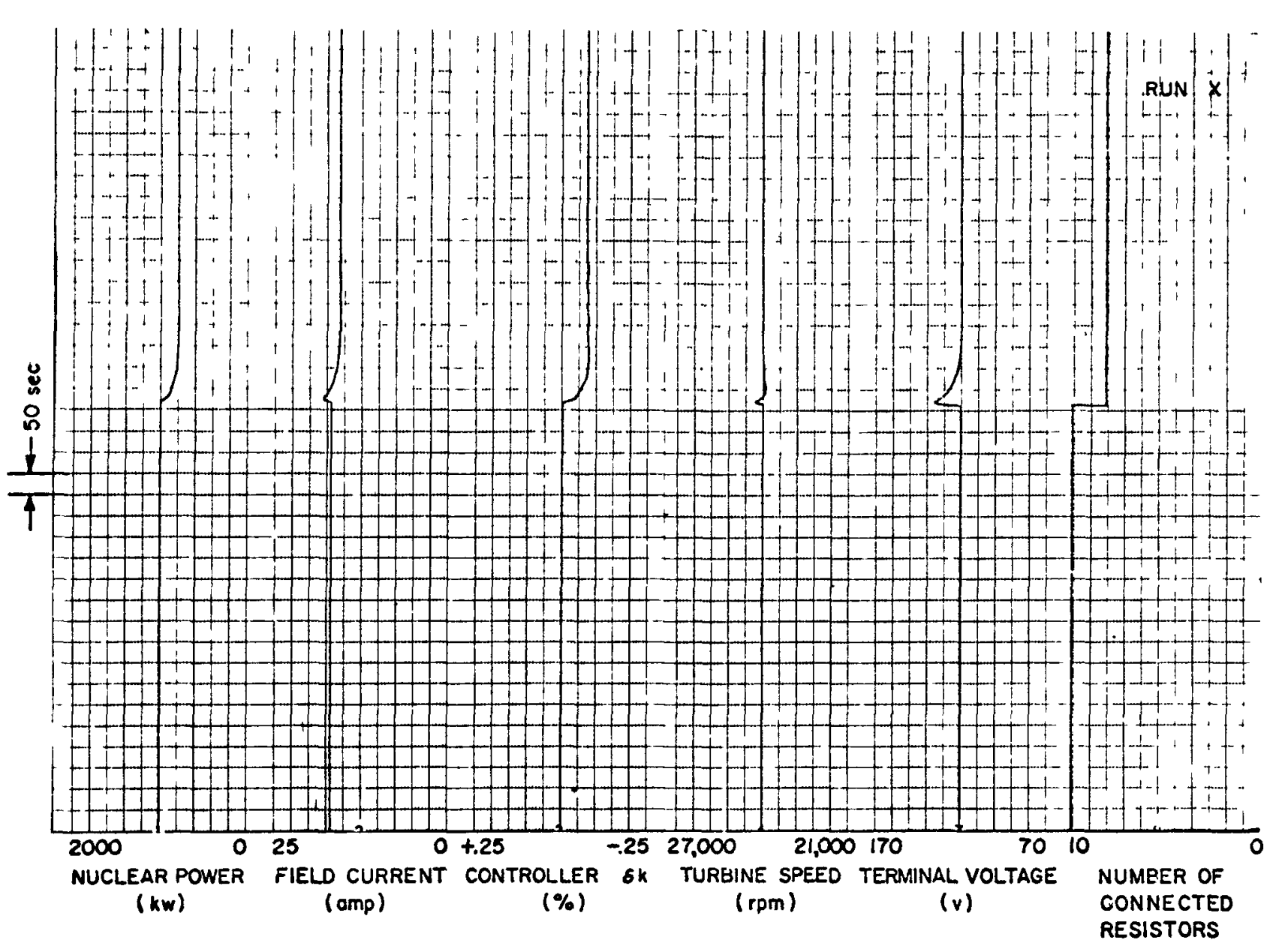

Fig. 5. System Response to a Sudden Loss of Two of Ten Equal Load Resistors with Control Scheme No. 1. 


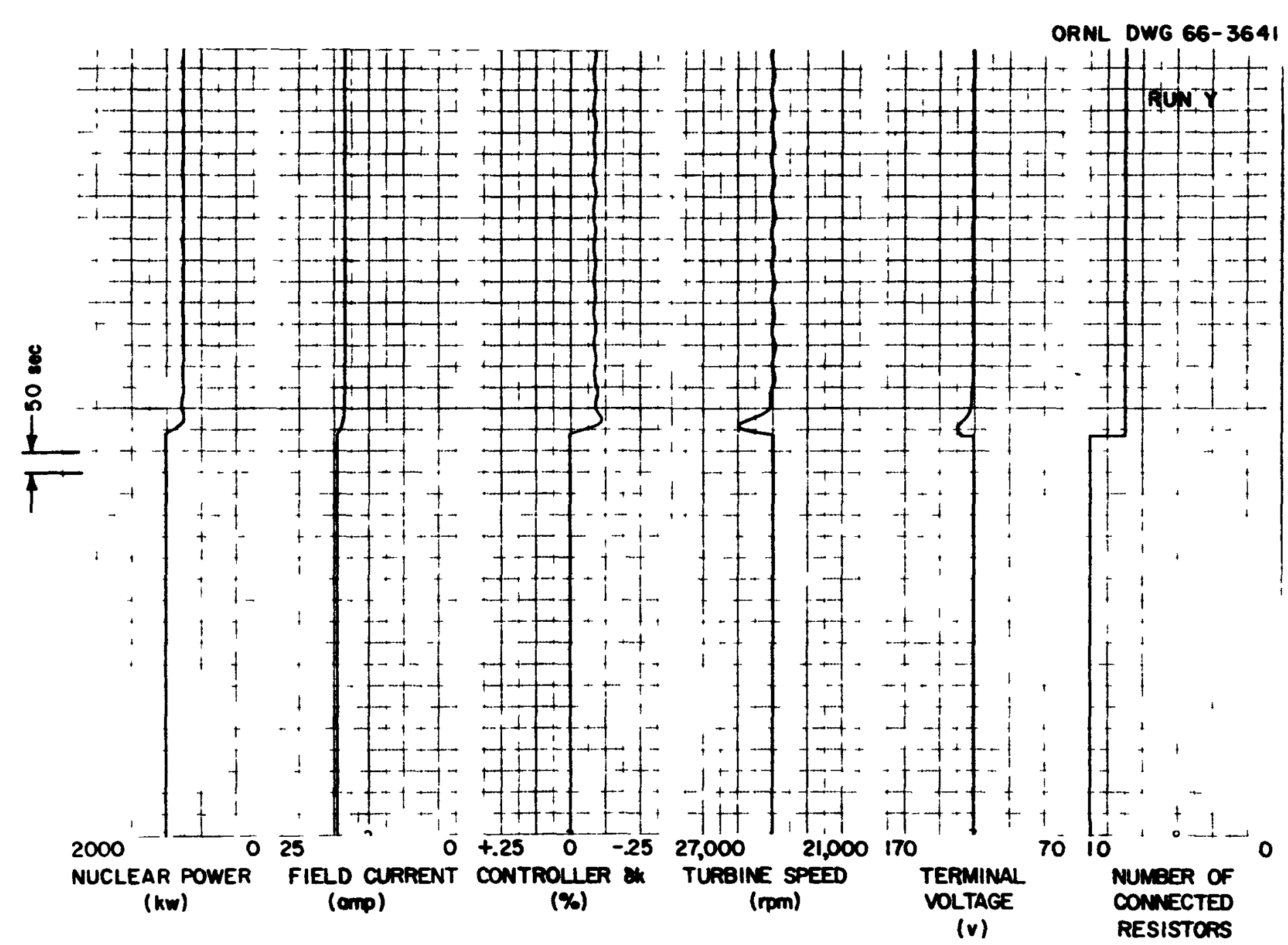

Fig. 6. System Response to a Sudden Loss of Two of Ten Equal Load Resistors with Control Scheme No. 2. 


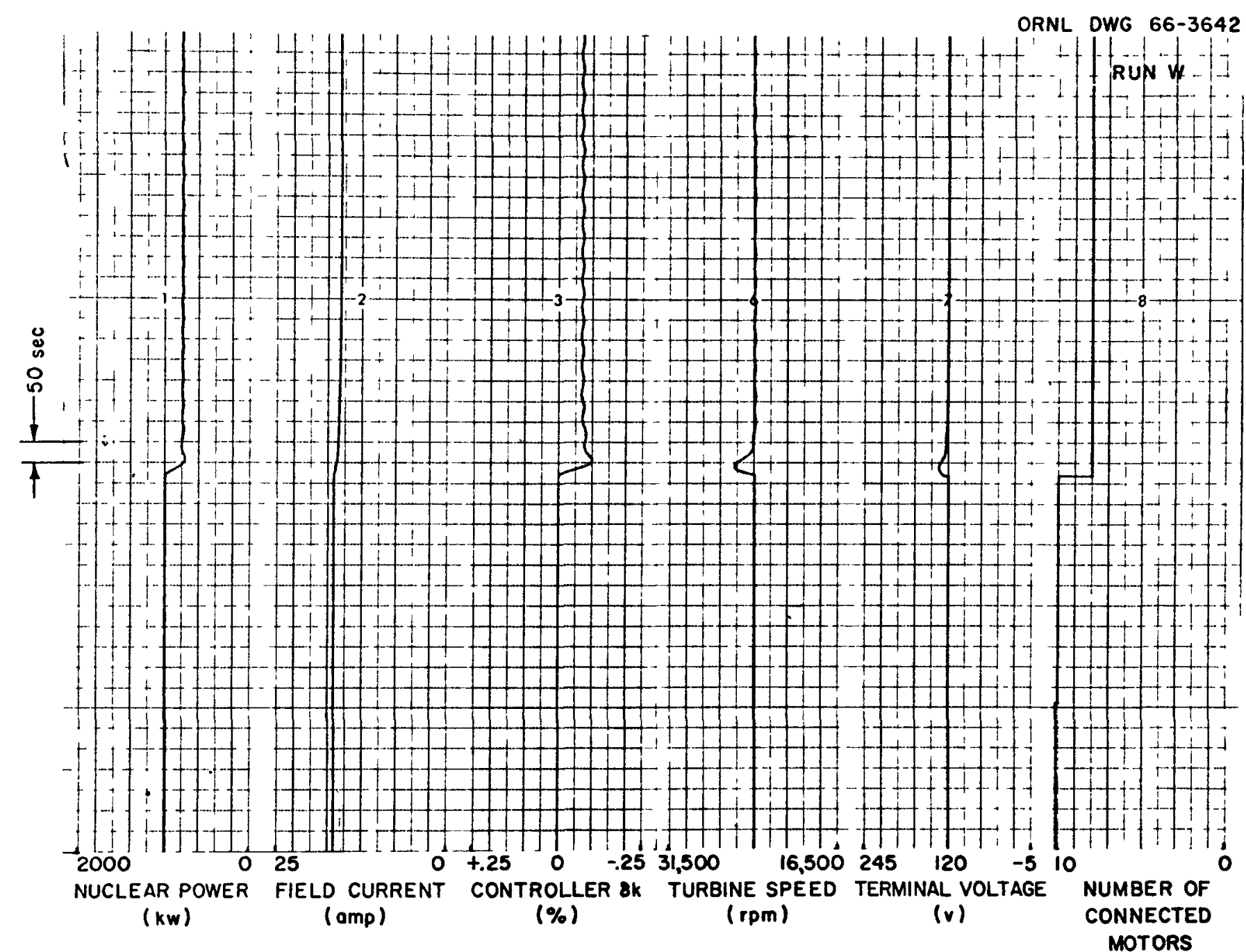

Fig. 7. System Response to a Sudden Loss of Two of the Ten Equal Motor Loads with Control Scheme No. 2 . 


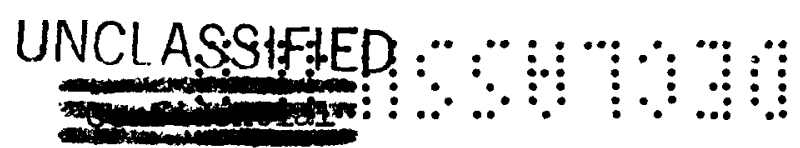

19

\section{CONCLUSTONS}

Time lags in the system are relatively short primarily because of the small thermal inertia of the boller and the small vapor volumes in the boiler and in the piping between the boiler and the turbine. The shortness of these time lags favored plant controllability.

The plant with resistive loads can be controlled by either of the two proposed control schemes; however, Scheme No. 1 is more stable than Scheme No. 2.

When the system load is approximately like that of induction motorariven pumps, Control Scheme No. 1 is highly unstable. Control Scheme No. 2 works fairly well, but the system continues to oscillate somewhat following a system perturbation.

The type of control system required is quite sensitive to the nature of the load. In particular, the behavior of the attached loads during off-normal frequency and voltage conditions (as for example the change in input characteristics of power conditioning equipment) will be a major factor in the design of an integrated control system for the plant. 
page blank 


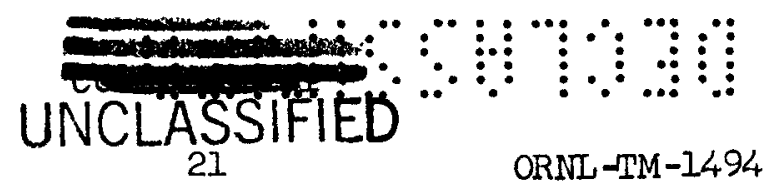

INPERNAL DISTRIBUTION

1. G. M. Adamson, Jr.
2. S. J. Ball
3. A. R. Barbin
4. S. E. Beall
5. S. E. Bolt
6. C. J. Borkowski
7. O. W. Burise
8. H. C. Claiborne
9. F. L. Culler
10. J. E. Cunningham
11. R. A. Dandl
12. J. H. DeVan
13-22. S. J. Ditto
23. E. P. Epler
24. J. Foster
25 44. A. P. Fraas
45. A. G. Grindell
46. W. O. Harms
47. C. S. Harrill
48. P. N. Haubenreich
49. S. I. Kaplan
50. P. R. Kasten
51. T. W. Kerlin
52. R. B. Korsmeyer
53. M. E. Lackey
54. M. E. LaVerne
55. M. I. Lundin

56. R. N. Lyon

57. H. G. MacPherson

58. R. E. MacPherson

59. H. C. McCurdy

60. J. W. Michel

61. A. J. Miller

62. A. M. Perry

63. G. Samuels

64. A. W. Savolainen

65. J. I. Scott

66. 0. I. Smith

67. I. Spiewak

68. A. Taboada

69. D. B. Trauger

70. C. S. Walker

71. A. M. Weinberg

72. J. R. Weir, Jr.

73. G. D. Whitman

74. J. V. Wilson

75-77. M. M. Yarosh

78. Gale Young

79. J. Zasler

80-81. Central Research Library

82-83. ORNL - Y-12 Technical Library Document Reference section

84-86. Laboratory Records

87. Laboratory Records (RC)

88. ORNL Patent Office

\section{EXTERNAL DISTRIBUTION}

89. C. H. Armbruster, Wright Air Development Center, Dayton, Ohio

90. D. Blancher, Lockheed, Burbank, California

91. G. K. Dicker, AEC, Washington

92. Sherman Edwards, Lockheed, Sacramento, California

93-102. H. B. Finger, AEC, Washington

103. Graham Hagey, NASA, Houston

104. Carl E. Johnson, AEC, Washington

105. J. D. Lafleur, AEC, Washington

106-110. Bernard Lubarsky, NASA, Lewis Research Center

111. James Lynch, NASA, Washington

112. Benjamin Pinkel, Rand Corp., Santa Monica, California

113. Fred Schulman, NASA, Washington

114. Abe Silverstein, NASA, Lewis Research Center

115-119. R. M. Spencer, AEC, Washington

120. Jack Stearns, JPL, Pasadena, California

121. H. J. Stewart, JPL, Pasadena, California

122. G. C. Szego, IDA, Arlington, Virginia 


\section{(Continued)}

123. T. F. Widmer, GE, Valley Forge, Philadelphia, Pennsylvania

124. Gordon Woodcock, NASA, Huntsville

125. W. Woodward, NASA, Washington

126-140. Division of Technical Information Extension (DTIE)

141. Research and Development Division, ORO

142-143. Reactor Division, ORO 